\title{
Act on the Registration and Evaluation of Chemicals (K-REACH) and replacement, reduction or refinement best practices
}

\author{
Soojin $\mathrm{Ha}^{1}$, Troy Seidle ${ }^{2}$, Kyung-Min Lim ${ }^{1,2}$ \\ ${ }^{1}$ Department of Mechanistic Toxicology, Ewha Womans University College of Pharmacy, Seoul, Korea; ${ }^{2}$ Research and \\ Toxicology Department, Humane Society International, Toronto, Canada
}

Objectives Korea's Act on the Registration and Evaluation of Chemicals (K-REACH) was enacted for the protection of human health and the environment in 2015. Considering that about 2000 new substances are introduced annually across the globe, the extent of animal testing requirement could be overwhelming unless regulators and companies work proactively to institute and enforce global best practices to replace, reduce or refine animal use. In this review, the way to reduce the animal use for K-REACH is discussed. Methods Background of the enforcement of the K-REACH and its details was reviewed along with the papers and regulatory documents regarding the limitation of animal experiments and its alternatives in order to discuss the regulatory adoption of alternative tests.

Results Depending on the tonnage of the chemical used, the data required ranges from acute and other short-term studies for a single exposure route to testing via multiple exposure routes and costly, longer-term studies such as a full two-generation reproducibility toxicity. The European Registration, Evaluation, Authorization and Restriction of Chemicals regulation provides for mandatory sharing of vertebrate test data to avoid unnecessary duplication of animal use and test costs, and obligation to revise data requirements and test guidelines "as soon as possible" after relevant, validated replacement, reduction or refinement (3R) methods become available. Furthermore, the Organization for Economic Cooperation and Development actively accepts alternative animal tests and $3 R$ to chemical toxicity tests.

Conclusions Alternative tests which are more ethical and efficient than animal experiments should be widely used to assess the toxicity of chemicals for K-REACH registration. The relevant regulatory agencies will have to make efforts to actively adopt and uptake new alternative tests and $3 \mathrm{R}$ to $\mathrm{K}-\mathrm{REACH}$.

Keywords Korea's Act on the Registration and Evaluation of Chemicals, Replacement, Reduction, Refinement, Alternative to animal test, Safety evaluation

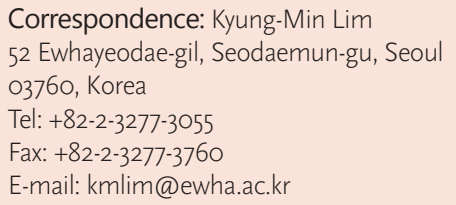

Received: September 28, 2016 Accepted: November 4, 2016 Published: December 19, 2016

This article is available from: http://e-eht.org/

\section{Introduction}

In modern society, chemicals are indispensable for everyday human life. Numerous chemicals are used to maintain and improve the quality of life, including cosmetics, toiletries, detergents, air fresheners, agrochemicals such as pesticides and fertil- izers, disinfectants, sterilizers, preservatives and industrial solvents. Chemicals are also employed in the manufacture of various product-comprising ingredients or parts like coatings/paints, photo-resistant treatments, batteries, automobiles, packaging and many more uncountable uses. One recent report estimated that as many as 80000 to 120000 chemicals are currently in use 
worldwide, with an additional 2000 chemicals newly introduced each year $[1,2]$. In Korea, approximately 44000 chemicals are known to be in use and about 300 new chemicals are newly marketed annually [3]. Accordingly, exposure to humans and the environment is unavoidable, which can be accompanied by adverse effects to human health and/or the environment.

The potential danger of chemical exposure and its devastating outcomes has been strikingly exemplified by the recent tragic accident surrounding oligo(2-(2-ethoxy)ethoxyethyl guanidine chloride/polyhexamethyleneguanidine, which were inadvertently used to sterilize humidifiers [4]. These chemicals, which were originally developed as carpet sterilizers, when used in humidifiers, resulted in high doses via inhalational exposure and unanticipated lung fibrosis, which cost 701 innocent lives, mostly newborn babies and nursing mothers $[5]$. To better protect humans and the environment against exposure to toxic chemicals, the Act on the Registration and Evaluation of Chemicals (K-REACH), was enacted and has been in force since 2015, mandating the registration of a chemical before its release onto the market with relevant information on human health and environmental hazards [6].

\section{Act on the Registration and Evaluation of Chemicals: Data Requirements, Test Guidelines and Skyrocketing Animal Use}

$\mathrm{K}-\mathrm{REACH}$ is the Korean version of the European Registration, Evaluation, Authorization and Restriction of Chemicals (EU-REACH) regulation. K-REACH originally aimed to manage the risk stemming from chemical exposure by providing relevant information on intrinsic hazards and guidance regarding safe use, such as by providing proper classification and labeling [7]. In this respect, it is aligned with the United Nation (UN) Globally Harmonized System of Classification and Labeling of Chemicals (GHS) [8]. The UN GHS hazard class system categorizes chemicals according to its level of health hazard as an axis and toxic outcomes or endpoints as another. Accordingly, the effects of chemicals on the respective toxic endpoints is evaluated to obtain safety data so the chemical can be properly classified. Depending on the volume or tonnage of the chemical used, the level and range of information required varies, as shown in Table 1. Notably, K-REACH does not incorporate many of the animal welfare provisions contained in its European counterpart regulation, e.g., the Article 1 requirement to pro-

Table 1. Requirement of data for Act on the Registration and Evaluation of Chemicals registration

\begin{tabular}{|c|c|c|c|c|}
\hline \multirow{2}{*}{ Field } & \multicolumn{4}{|c|}{ Tonnage [no. of test] ${ }^{\mathrm{a}}$} \\
\hline & $\geq 1-10<[15]$ & $\geq 10-100<[26]$ & $\geq 100-1000<[37]$ & $\geq 1000[47]$ \\
\hline $\begin{array}{l}\text { Physico- } \\
\text { chemical } \\
\text { property }\end{array}$ & $\begin{array}{l}\text { State of substance } \\
\text { Water solubility } \\
\text { Melting/freezing point } \\
\text { Boiling point } \\
\text { Vapor pressure } \\
\text { Octanol/water partitioning } \\
\text { coefficient } \\
\text { Density } \\
\text { Particle size analysis }\end{array}$ & $\begin{array}{l}\text { Flammability } \\
\text { Explosiveness } \\
\text { Oxidation }\end{array}$ & $\begin{array}{l}\text { Viscosity } \\
\text { Dissociation constant }\end{array}$ & \\
\hline $\begin{array}{l}\text { Hazard on } \\
\text { human } \\
\text { health }\end{array}$ & $\begin{array}{l}\text { Acute toxicity-oral } \\
\text { (acute toxicity-inhalation) } \\
\text { Ames test (bacterial reverse } \\
\text { mutation assay) } \\
\text { Skin irritation/corrosion } \\
\text { Skin sensitization }\end{array}$ & $\begin{array}{l}\text { Acute toxicity-dermal route or } \\
\text { inhalation } \\
\text { Eye irritation/corrosion } \\
\text { Chromosomal aberration test } \\
\text { Genotoxicity test } \\
\text { Repeated dose toxicity study (28 d) } \\
\text { Screening for reproductive/ } \\
\text { developmental toxicity }\end{array}$ & $\begin{array}{l}\text { Additional genotoxicity test } \\
\text { (reproductive cell and genotoxicity) }\end{array}$ & $\begin{array}{l}\text { Repeated dose toxicity study (90 d) } \\
\text { Teratogenicity } \\
\text { Two-generation reproductive toxicity } \\
\text { Carcinogenicity }\end{array}$ \\
\hline $\begin{array}{l}\text { Hazard on the } \\
\text { environment }\end{array}$ & $\begin{array}{l}\text { Acute toxicity on fish } \\
\text { Ready biodegradability } \\
\text { Acute daphnia } \\
\text { immobilization test }\end{array}$ & $\begin{array}{l}\text { Fresh water algae growth } \\
\text { inhibition test } \\
\text { Biodegradation as a function of } \mathrm{pH}\end{array}$ & $\begin{array}{l}\text { Inherent biodegradability } \\
\text { Identification of degradation products } \\
\text { Chronic toxicity on fish } \\
\text { Chronic toxicity on preferred species } \\
\text { daphnia } \\
\text { Acute toxicity on terrestrial plants } \\
\text { Activated sludge respiration inhibition } \\
\text { Adsorption/desorption }\end{array}$ & $\begin{array}{l}\text { Further information on the } \\
\text { environmental fate and behavior } \\
\text { Chronic toxicity on terrestrial plants } \\
\text { Chronic toxicity testing on terrestrial } \\
\text { invertebrates } \\
\text { Further information on adsorption/ } \\
\text { desorption depending on the } \\
\text { results of the study } \\
\text { Long-term toxicity to sediment } \\
\text { organisms } \\
\text { Bio-concentration }\end{array}$ \\
\hline
\end{tabular}

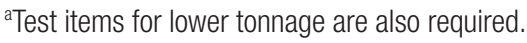


mote alternatives to animal testing, the Article 13 requirement to generate new data wherever possible by means other than vertebrate animal tests, the Article 25 requirement to avoid unnecessary testing, and the Annex XI rules for waiving or otherwise adapting standard data requirements [9]. According to the list of tests required by K-REACH shown in Table 1, for chemical substances manufactured or imported in volumes of 1000 tons or more per year, the data package must include 46 test items; this entails a huge amount of money and resources. Furthermore, to generate health hazard and ecotoxicology packages using conventional test guideline methods, the animal use would be astronomical. In the worst case scenario, the number of animals required per substance would be nearly 6000, just for the assessment of human health effects, at a cost of more than 1.5 billion Korean won. The number of animals required and the costs for each test are listed in Table 2.

Given that about 300 chemicals are newly introduced into Korean market every year, the use of animals would be enormous without any drastic changes. Statistics published recently by the Korean Ministry of Agriculture, Food and Rural Affairs (MAFRA) reflects a $36.7 \%$ increase in experimental animal use between 2012 and 2015 (2012, 1834000; 2013, 1967000; 2014, 2412000; 2015,2507000 ) [10]. This problem is not unique to Korea. Following the enactment of REACH in the EU, the European Chemicals Agency has estimated that 30000 substances will be registered, requiring upwards of 3.9 million animals to be used in tests costing $€ 1.6$ billion (US\$ 2.3 billion) [11,12]. However, others have suggested that the European Chemicals Agency's estimates may represent a substantial underestimation of both chemical registrations and animal use, projecting on the order of 68000 substance registrations and use of 54 million animals, respectively
[13]. Thus, the European public has demanded swift action by authorities and industry to ensure effective sharing of existing data, uptake of validated alternatives to animal tests, and other scientifically supported replacement, reduction or refinement (3R) best practices.

\section{Limitation and Problems of Conventional Animal Experiments}

Conventional animal experiments have been developed and used on the premise that the responses of animals in the laboratory to chemicals can provide information to predict those of humans in the real world. However, this basis is somewhat incorrect with respect to species differences in genetic expression, absorption, distribution, metabolism and excretion, organ susceptibility, immune responses and resistance or tolerance to xenobiotics. This point has been explicitly criticized by Leist and Hartung [14], who stated that "the human is not a $70 \mathrm{~kg}$ rat." Indeed, rats, one of the most widely exploited experimental animal species, have different metabolic capacity and immune responses to humans, which seriously undermines the predictability of the experimental data [15]. Another important point which diminishes the utility of animal experiments is that extreme conditions are generally employed as the "worst case scenario" in view of chemical exposure levels (extremely high doses ranging from 10-fold to 1000-fold higher than human exposure levels) [16], exposure route (forced eyelid eversion for ocular irritant administration and closure for persistent exposure, or injection into sutured oral pouches to simulate oral mucosal exposure), stress (unrealistically stressful conditions like cold or hot conditions), or disease states (no animal naturally exhibits an asthma-

Table 2. Number of animals required for the assessment of human health effects

\begin{tabular}{|c|c|c|c|c|}
\hline & Cost $^{\mathrm{a}}$ per substance & Primary species & Second species & Primary species (second cohorts) \\
\hline Acute toxicity for oral & $2948571^{b}$ & 24 & & \\
\hline Acute toxicity for dermal or inhalation & $3338333^{b}$ & 40 & & \\
\hline Skin irritation and corrosion & $3186000^{b}$ & 3 & & \\
\hline Skin sensitization & $13195000^{b}$ & 45 & & \\
\hline Eye irritation and corrosion & $3186000^{\mathrm{b}}$ & 3 & & \\
\hline Repeated dose toxicity (28 d) & $78637500^{\mathrm{b}}$ & 60 & 60 & \\
\hline Repeated dose toxicity (90 d) & $90000000^{c}$ & 120 & 100 & \\
\hline In vivo mutagenicity/genotoxicity & $9580517^{b}$ & $25-80$ & & \\
\hline Carcinogenicity & $1000000000^{c}$ & 500 & 500 & \\
\hline Two generation & $270000000^{c}$ & 200 & 240 & \\
\hline \multicolumn{5}{|l|}{ Reproductive toxicity } \\
\hline Reproductive toxicity screening & $62000000-70000000^{c}$ & 675 & & \\
\hline Total & 1540071921 & & & 5975 \\
\hline
\end{tabular}

GLP, good laboratory practice; CRO, contract research organization.

aUnit Korean won.

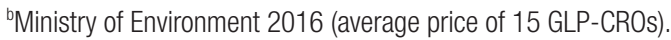

'From a single GLP-CRO. 
like syndrome that is similar to the disease in humans) [17].

Although these experimental approaches may save time (using a high dose to curtail the time factor) and cost, they frequently produce unrealistic and inaccurate dose-response data for the prediction of human responses. Exemplifying this, endocrine disrupting chemicals generally exhibit unconventional non-linear, bell-shaped or U-shaped dose-response patterns that cannot be properly evaluated in high-dose animal experiments [18]. The dose-limiting toxicity of drug candidates observed in animal tests mostly do not appear in human clinical trials and the poor predictability of animal experiments has been observed across diverse target tissues [19]. Due to the failure of clinical trials by the appearance of unscreened toxicity during preclinical trials, enormous amounts of money and time are wasted [20]. In this context, the development of more human-relevant and advanced methods is necessary to replace or at least to supplement traditional animal tests.

In addition to the major scientific drawbacks described above, animal tests have been criticized for their inherent cruelty, for being excessively time-intensive and resource-intensive, restrictive in the number of substances or mixtures that can be tested, and of little value in understanding the mechanistic underpinnings of toxicity in the species of ultimate interest.

\section{New Methods as Replacements for Conventional Animal Tests}

The last century has witnessed unprecedented scientific and technological advances in biology, represented by human whole genome sequencing [21], the birth of functional genomics [22], computational biology, and high-speed robot automation of cellbased (in vitro) screening systems [23]. These innovations are being incorporated into a wide range of health and molecular/ cellular biological research sectors, providing renewed vigor and inspiration in these areas. Numerous novel and revolutionary biochemical and molecular tools have been developed through this innovation, including high throughput assays, quantitative real time-polymerase chain reaction, flow cytometry, high content assays, gene transfection, reporter gene assays and tissue engineering. in fact, these new tools have helped to understand how toxicants disrupt the normal physiology of the human body at the cellular and molecular levels, which has contributed to the birth of molecular and mechanistic toxicology [24]. The resulting predictions regarding human safety and the risk of a chemical are potentially more relevant to people than animal tests. In line with this, the Toxicology for the 21st Century or "Tox 21 " strategy has been embarked on with a grand vision "to innovate virtually all routine toxicity testing to be conducted in human cells or cell lines" [25]. These non-animal based new testing methods enable safety evaluations of a much larger number of substances, in a more rapid, efficient and cost-effective way. Most importantly, these methods are likely to be more relevant to toxicity in humans, as well as capable of identifying the cellular mechanisms of toxicity using fewer or no animals [26,27].

\section{Development of Non-animal Based Alternatives and Their Adoption by Regulatory Science}

Safety and regulatory science is one of most conservative and slowest-moving sectors in taking up new and novel methods, since many countries with diverse cultural and socioeconomic backgrounds must comply with new regulation through so-called "international and inter-regional harmonization". Moreover, there are various stakeholders with conflicting interests even within a single country. This is understandable, since important policies like drinking water standards, sewage control, emission limits, inclusion on positive or negative lists, and authorizing the use of chemicals are based upon safety evaluations and risk assessments, which often cost enormous amounts of money to achieve compliance, with serious risks to public health or the environment in the absence of compliance. Prior to implementation, a newly developed method must be compared regarding its relevance and reliability to the original gold standard method or targeted toxicity endpoint in humans in a validation trial, which can take as long as 10 years from the initial research and development steps [28]. The results of validation studies are then subject to regulatory adoption processes, involving appraisal by experts with multi-disciplinary backgrounds, often with the participation of more than one regulatory body from multiple countries.

International regulatory bodies or collaborative organizations that can represent a large number of countries, like the Organization for Economic Cooperation and Development (OECD), the International Conference on Harmonization of Technical Requirements for Registration of Pharmaceuticals for Human Use and the International Organization for Standardization have participated in these review and appraisal processes to accommodate the opinions of member countries. Of these, the OECD is the most active in publishing and updating new test guidelines (TGs), along with integrated approaches to testing and assessment and other guidance materials, which 35 member countries can follow as the standardized methods. Many in vitro or in vivo tests with animal replacement, reduction or refinement potential have been included as TGs recently, as shown in Table 3 [29], indicating 3R concepts applied to TGs, which are classified according to toxic endpoints. While non-animal tests have been 
Table 3. OECD TGs and number of animal reduction by an alternative test methods based on 3R

\begin{tabular}{|c|c|c|c|c|c|c|}
\hline Toxic endpoint & $\begin{array}{l}\text { OECD TG } \\
\text { No. }\end{array}$ & Title & $\begin{array}{l}\text { In vivo/ } \\
\text { in vitro }\end{array}$ & $3 R$ & Year & $\begin{array}{c}\text { No. of } \\
\text { animals used }\end{array}$ \\
\hline \multirow[t]{3}{*}{ Acute toxicity } & 420 & Acute oral toxicity: fixed dose procedure & In vivo & Refinement & 2002 & 20 \\
\hline & 423 & Acute oral toxicity: acute toxic class method & In vivo & Reduction & 2002 & 12 \\
\hline & 425 & Acute oral toxicity: up-and-down procedure & In vivo & $\begin{array}{l}\text { Refinement/ } \\
\text { reduction }\end{array}$ & 2008 & 9 \\
\hline \multirow{5}{*}{$\begin{array}{l}\text { Skin irritation and } \\
\text { corrosion }\end{array}$} & 404 & Acute dermal irritation/corrosion & In vivo & Refinement & 2015 & $3-4$ \\
\hline & 430 & In vitro skin corrosion: transcutaneous electrical resistance test method & In vitro & Replacement & 2015 & 0 \\
\hline & 431 & In vitro skin corrosion: reconstructed human epidermis test method & In vitro & Replacement & 2015 & 0 \\
\hline & 435 & In vitro membrane barrier test method for skin corrosion & In vitro & Replacement & 2015 & 0 \\
\hline & 439 & In vitro skin irritation: reconstructed human epidermis test method & In vitro & Replacement & 2015 & 0 \\
\hline \multirow[t]{6}{*}{ Skin sensitization } & 429 & Skin sensitization: local lymph node assay & In vivo & Reduction & 2010 & 24 \\
\hline & $442 \mathrm{~A}$ & Skin sensitization: local lymph node assay: DA & In vivo & $\begin{array}{l}\text { Refinement/ } \\
\text { reduction }\end{array}$ & 2010 & 24 \\
\hline & $442 \mathrm{~B}$ & Skin sensitization: local lymph node assay: BrdU-ELISA & In vivo & $\begin{array}{l}\text { Refinement/ } \\
\text { reduction }\end{array}$ & 2010 & 24 \\
\hline & $442 \mathrm{C}$ & In chemico skin sensitization: direct peptide reacitivity assay & In vitro & Replacement & 2015 & 0 \\
\hline & $442 D$ & In vitro skin sensitization: ARE-Nrf2 luciferase test method & In vitro & Replacement & 2015 & 0 \\
\hline & $442 \mathrm{E}$ & In vitro skin sensitisation: human cell line activation test & In vitro & Replacement & 2016 & 0 \\
\hline \multirow{6}{*}{$\begin{array}{l}\text { Eye irritation and } \\
\text { corrosion }\end{array}$} & 405 & Acute eye irritation/corrosion & In vivo & Refinement & 2012 & $1-3$ \\
\hline & 437 & Bovine corneal opacity and permeability test method & In vitro & Replacement & 2013 & 0 \\
\hline & 438 & Isolated chicken eye test method & In vitro & Replacement & 2013 & 0 \\
\hline & 460 & $\begin{array}{l}\text { Fluorescein leakage test method for identifying ocular corrosives and } \\
\text { severe irritants }\end{array}$ & In vitro & Replacement & 2012 & 0 \\
\hline & 491 & $\begin{array}{l}\text { Short time exposure In vitro test method for identifying; i) chemicals } \\
\text { inducing serious eye damage and ii) chemicals not requiring } \\
\text { classification for eye irritation or serious eye damage }\end{array}$ & In vitro & Replacement & 2015 & 0 \\
\hline & 492 & $\begin{array}{l}\text { Reconstructed human cornea-like epithelium test method for identifying } \\
\text { chemicals not requiring classification and labelling for eye irritation or } \\
\text { serious eye damage }\end{array}$ & In vitro & Replacement & 2015 & 0 \\
\hline $\begin{array}{l}\text { Dermal/ percutaneous } \\
\text { absorption }\end{array}$ & 428 & Skin absorption: in vitro method & In vitro & Replacement & 2004 & 0 \\
\hline \multirow{11}{*}{$\begin{array}{l}\text { Mutagenicity/ } \\
\text { genotoxicity }\end{array}$} & 471 & Bacterial reverse mutation test & In vitro & Replacement & 1997 & 0 \\
\hline & 473 & In vitro mammalian chromosomal aberration test & In vitro & Replacement & 2014 & 0 \\
\hline & 474 & Mammalian erythrocyte micronucleus test & In vivo & Refinement & 2014 & $23-35$ \\
\hline & 475 & Mammalian bone marrow chromosomal aberration test & In vivo & Refinement & 2014 & 45 \\
\hline & 476 & In vitro mammalian cell gene mutation tests using the hprt and xprt genes & In vitro & Replacement & 2015 & 0 \\
\hline & 478 & Rodent dominant lethal test & In vivo & Refinement & 2015 & $96-120$ \\
\hline & 483 & Mammalian spermatogonial chromosomal aberration test & In vivo & $\begin{array}{l}\text { Refinement/ } \\
\text { reduction }\end{array}$ & 2015 & 45 \\
\hline & 487 & In vitro mammalian cell micronucleus test & In vitro & Replacement & 2014 & 0 \\
\hline & 488 & Transgenic rodent somatic and germ cell gene mutation assays & In vivo & Refinement & 2013 & 25 \\
\hline & 489 & In vivo mammalian alkaline comet assay & In vivo & $\begin{array}{l}\text { Refinement/ } \\
\text { reduction }\end{array}$ & 2014 & $25 \sim 35$ \\
\hline & 490 & In vitro mammalian cell gene mutation tests using the thymidine kinase gene & In vitro & Replacement & 2015 & 0 \\
\hline \multirow[t]{3}{*}{ Reproductive toxicity } & 421 & Reproduction/developmental toxicity screening test & In vivo & $\begin{array}{l}\text { Refinement/ } \\
\text { reduction }\end{array}$ & 2015 & 90 \\
\hline & 422 & $\begin{array}{l}\text { Combined repeated dose toxicity study with the reproduction/ } \\
\text { developmental toxicity screening test }\end{array}$ & In vivo & $\begin{array}{l}\text { Refinement/ } \\
\text { reduction }\end{array}$ & 2015 & 90 \\
\hline & 443 & Extended one- generation reproductive toxicity study & In vivo & $\begin{array}{l}\text { Refinement/ } \\
\text { reduction }\end{array}$ & 2012 & 140 \\
\hline Photo-induced toxicity & 432 & In vitro 3T3 NRU phototoxicity test & In vitro & Replacement & 2004 & 0 \\
\hline Carcinogenicity & 453 & Combined chronic toxicity/carcinogenicity studies & In vivo & Reduction & 2009 & 560 \\
\hline
\end{tabular}

OECD, Organization for Economic Cooperation and Development; TG, test guidelines; 3R, replacement, reduction or refinement; BrdU-ELISA, bromodeoxyuridine-enzyme-linked immunosorbent assay; ARE-Nrf2, antioxidant responsive element binded NF-E2-related factor 2; DA, developed by Daicel Chemical Industries, Ltd; NRU, neutral red uptake.

actively developed and widely used in skin or eye irritation tests, the alternative tests are not yet established for acute toxicity or re- provductive toxicity.

OECD TGs on toxicity tests were first developed in early 1980s, 


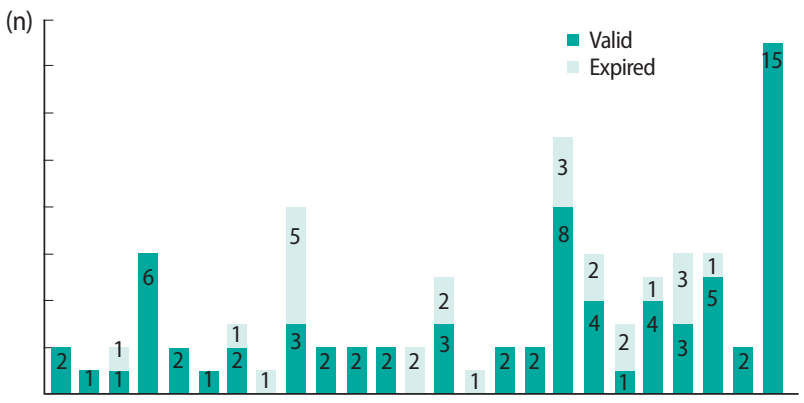

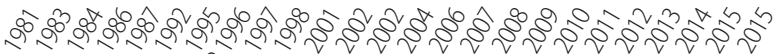

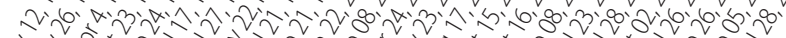

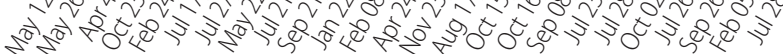

Figure 1. Number of revision or updates of Organization for Economic Cooperation and Development test guideline by Dec 2015 and have been revised continuously by $3 \mathrm{R}$ concepts and with the progression of science. From the 1980s to the early 2000s, mainly in vivo methods using animals were adopted as TGs, and the pace of development or the appearance of new methods was slow. However, since the late 2000s, the TGs have been annually revised with $3 \mathrm{R}$ concepts, and many new alternative animal tests have been adopted (Table 3), and many old or obsolete TGs can now be abandoned. The number of TG revisions by year is shown in Figure 1 [27].

Human biology-based in vitro methods are typically more relevant and predictive, less time-consuming, can accommodate larger number of chemicals or mixtures than traditional animal experiments, and can address the mechanism of toxicity using

Table 4. Category and tools employed for OECD TGs based on non-animal based methodology

\begin{tabular}{|c|c|c|c|c|}
\hline Category & OECD TG No. & Toxi endpoints & Title & System and tools employed \\
\hline \multirow[t]{3}{*}{ Ex vivo } & 437 & Eye irritation/corrosion & $\begin{array}{l}\text { Bovine corneal opacity and permeability test } \\
\text { method }\end{array}$ & $\begin{array}{l}\text { Isolated corneas from the eyes of cattle } \\
\text { slaughtered (UV absorbance/Opacimeter) }\end{array}$ \\
\hline & 438 & Eye irritation/corrosion & Isolated chicken eye test method & $\begin{array}{l}\text { Eyes of slaughtered chicken } \\
\text { (slit-lamp microscopes) }\end{array}$ \\
\hline & 460 & Eye irritation/corrosion & $\begin{array}{l}\text { Fluorescein Leakage test method for identifying } \\
\text { ocular corrosives and severe irritants }\end{array}$ & $\begin{array}{l}\text { Confluent monolayer of Madin-Darby canine } \\
\text { kidney (UV absorbance) }\end{array}$ \\
\hline \multirow[t]{15}{*}{ In vitro } & 430 & Skin corrosion & $\begin{array}{l}\text { In vitro skin corrosion: transcutaneous electrical } \\
\text { resistance test method }\end{array}$ & Rat skin disk (voltohmmeter) \\
\hline & 431 & Skin corrosion & $\begin{array}{l}\text { In vitro skin corrosion: reconstructed human } \\
\text { epidermis test method }\end{array}$ & $\begin{array}{l}\text { Reconstructed human epidermis } \\
\text { (3D tissue engineering) }\end{array}$ \\
\hline & 435 & Skin corrosion & $\begin{array}{l}\text { In vitro membrane barrier test method for skin } \\
\text { corrosion }\end{array}$ & Artificial membrane \\
\hline & 439 & Skin irritation & $\begin{array}{l}\text { In vitro skin irritation: reconstructed human } \\
\text { epidermis test method }\end{array}$ & $\begin{array}{l}\text { Reconstructed human epidermis } \\
\text { (3D tissue engineering) }\end{array}$ \\
\hline & $442 D$ & Skin sensitization & $\begin{array}{l}\text { In vitro skin sensitization: ARE-Nrf2 luciferase } \\
\text { test method }\end{array}$ & $\begin{array}{l}\text { Cell line which contains the luciferase gene } \\
\text { under the transcriptional control of a } \\
\text { constitutive promoter fused with an are element } \\
\text { (reporter gene assay) }\end{array}$ \\
\hline & $442 \mathrm{E}$ & Skin sensitization & $\begin{array}{l}\text { In vitro skin sensitisation: human cell line } \\
\text { activation test }\end{array}$ & Human monocytic leukaemia cell line THP-1 \\
\hline & 491 & Eye irritation/corrosion & $\begin{array}{l}\text { Short time exposure in vitro test method for } \\
\text { identifying i) chemicals inducing serious eye } \\
\text { damage and ii) chemicals not requiring } \\
\text { classification for eye irritation or serious eye } \\
\text { damage }\end{array}$ & Statens seruminstitut rabbit cornea cells \\
\hline & 492 & Eye irritation/corrosion & $\begin{array}{l}\text { Reconstructed human cornea-like epithelium test } \\
\text { method for identifying chemicals not requiring } \\
\text { classification and labelling for eye irritation or } \\
\text { serious eye damage }\end{array}$ & $\begin{array}{l}\text { Reconstructed human cornea-like epithelium } \\
\text { (3D tissue engineering) }\end{array}$ \\
\hline & 428 & Dermal/percutaneous absorption & Skin absorption: in vitro method & Viable or non-viable human (animal) skin \\
\hline & 471 & Mutagenicity/genotoxicity & Bacterial reverse mutation test & Salmonella typhimurium, escherichia coli \\
\hline & 473 & Mutagenicity/genotoxicity & In vitro mammalian chromosomal aberration test & Mammalian somatic cells \\
\hline & 476 & Mutagenicity/genotoxicity & $\begin{array}{l}\text { In vitro mammalian cell gene mutation tests } \\
\text { using the HPRT and XPRT genes }\end{array}$ & Mammalian cells (ex. cho, chl) \\
\hline & 487 & Mutagenicity/genotoxicity & In vitro mammalian cell micronucleus test & Mammalian cells (ex. blood lymphocytes) \\
\hline & 490 & Mutagenicity/genotoxicity & $\begin{array}{l}\text { In vitro mammalian cell gene mutation tests } \\
\text { using the thymidine kinase gene }\end{array}$ & $\begin{array}{l}\text { L5178Y tk+/-3.7.2C cells for the mouse } \\
\text { lymphoma assay, TK6 tk+/- cells for the TK6 } \\
\text { assay }\end{array}$ \\
\hline & 432 & Photo-cytotoxicity & In vitro 3T3 NRU phototoxicity test & Balb/c 3T3 cells \\
\hline In chemico & $442 \mathrm{C}$ & Skin sensitization & $\begin{array}{l}\text { In chemico skin sensitization: direct peptide } \\
\text { reactivity assay }\end{array}$ & Synthetic peptides (LC/UV) \\
\hline
\end{tabular}

OECD, Organization for Economic Cooperation and Development; TG, test guideline; UV, ultraviolet; 3D, three-dimensional; HPRT, hypoxanthine-guanine phosphoribosyl transferase; XPRT, xanthine phosphoribosyl transferase; NRU, neutral red uptake; LC, liquid chromatography. 
the framework of an adverse outcome pathway (AOP). By systemically categorizing the biological events leading to adverse effects into key events between two points, i.e., a molecular initiating event and an adverse outcome, the AOP describes an adverse outcome following exposure to a chemical by a series of key events and key event relationships that describe the causal relationships between the key events. AOPs are instrumental for establishing the toxic mechanism of an adverse outcome and the utilization of safety test data at the in vitro, in vivo and human levels for risk assessments and regulatory applications. In the best case scenario, the number of animals saved by employing multiple in vitro tests along with limited in vivo tests will be in the thousands, which will significantly contribute to animal ethics without compromising predictive capacity or risking human health or environmental protection.

\section{Pros and Cons of In Vitro Alternatives to Animal Tests}

Ultimately and ideally, all animal experiments, including those with refined or reduced use of animals, are to be changed into non-animal based methods. These methods can be largely categorized into in chemico, ex vivo and in vitro methods. Approved OECD TGs fall into these categories, as shown in Table 4.

Since these methods largely employ test-tube or multi-well plate formats, the throughput is much higher than traditional animal experiments. For example, the $3 \mathrm{D}$ reconstructed human cornea-like epithelium ( $\mathrm{RhCE}$ ) method can evaluate the ocular irritancy of 10 test substances in one run, which takes three days from the delivery of the model [28]. This test is equivalent to 10 tests using the in vivo Draize rabbit eye irritation test, costing the lives 30 of rabbits and taking at least 10 days from the delivery of the rabbits [30]. This test can be harnessed to assess multiple combinations of test conditions like different mixture ratios, diverse exposure scenarios and the addition of metabolic capacity using a feasible amount of time and money [27]. Moreover, through targeting a single molecular event on the AOP framework, the conclusions of alternative methods may be more direct and straightforward, which is critical to address the mechanism of toxicity and extrapolation into human responses. For example, in the direct peptide reactivity assay, an in chemico skin sensitization test that addresses the haptenization response of a substance, positive results indicate that the chemical is reactive and can form protein adducts [31].

Of course, there are limitations and shortcomings of non-animal methods as well. First, most of the alternatives have not advanced into the level of risk assessment, since they only give a qualitative "yes" or "no" answer, namely hazard identification.
Even though some methods give quantitative data, their utility for potency classification or risk assessment has not been fully validated [32]. In addition, since the alternatives address mostly a single key event in the series of events constituting a larger AOP, they cannot provide the full mechanistic information regarding the final outcome of the initial exposure [33]. In this case, a combination of multiple in vitro assays can be used as an integrated approach to testing and assessment (IATA) [34]. Indeed, considerable efforts have been directed toward developing a standardized IATA scheme.

\section{Barriers to Acceptance of Non-animal Based Alternatives in Act on the Registration and Evaluation of Chemicals and Recommendations}

Although many validated and internationally recognized nonanimal methods and strategies are now available and ready for immediate use in regulatory frameworks such as K-REACH, their uptake by Korean authorities continues to be less than optimal. Whereas EU-REACH data requirements and guidance have been or are being amended to incorporate all available OECD 3R TGs and related best practices, such is not yet the case with K-REACH $[35,36]$. This is in part due to the lack of a "mandatory 3R" requirement under K-REACH and other legislation for the uptake of new methods. In addition, there is a lack of inter-ministerial cooperation regarding the uptake of new methods. For example, the Korean Centre for the Validation of Alternative Methods has been established under the Ministry of Food and Drug Safety (MFDS), but does not currently include participation from other regulatory or research agencies in the development, validation or regulatory review of non-animal based methods [37], indicating the inter-ministerial inefficiency and passive attitudes towards new and more advanced methods. Delayed implementation of 3R-based alternatives, due to these inefficiencies, would lead to the unnecessary sacrifice of laboratory animals, even though they are not better than new alternatives for the protection of human health and the environment.

There are also duplicate experiments for substances that have already been tested and assigned GHS classifications, including chemicals that are known corrosives, fatal if inhaled or probable carcinogens. The scientific basis for duplicating well-established test results and regulatory classifications is incomprehensible, particularly where vertebrate animal testing would be involved, and most notably where such testing (e.g., of corrosives) would result in the most extreme pain and suffering for the animals involved.

To ensure that the Korean regulatory framework for chemicals, and the general approach to the validation and adoption of 
3R best practices, do not fall farther behind those of other developed nations, K-REACH data requirements and TGs must be immediately and frequently amended on regular basis to incorporate all relevant OECD 3R TGs and related best practices, including mandatory data sharing, chemical grouping and readacross to ensure maximum possible reduction of vertebrate animal use and no duplication of existing test results. One overarching regulatory body shall be formed to include all Korean ministries with a stake in alternative methods and safety assessment, including the MFDS, the Ministry of Environment (MOE), and the MAFRA to facilitate inter-ministerial cooperation toward the development of a comprehensive government strategy and funding framework for the reduction and replacement of animals used for toxicity testing and life sciences research [38].

\section{Conclusion}

The implementation of K-REACH will contribute to the safe use of chemicals by identifying human health effects and ecotoxicity before their introduction to human society and the environment. However, a huge number of laboratory animals are required to comply with the current Korean guidelines, which is sometimes unnecessary and can be replaced with alternative methods. Therefore, in order for K-REACH to be more practically implemented, $3 \mathrm{R}$ concepts and alternative to animal tests (AATs) should be actively accepted, which has been advanced in the developed countries. Using AATs for safety assessment is scientific, highly reliable and predictable and may be more human-relevant without inflicting pain and death in laboratory animals. Moreover, the application of AATs may be more economical and effective than animal tests. The implementation of AATs is also a concern in other chemical sectors such as the food, cosmetics, drug and agrochemical industries. In this regard, the collaboration of the MOE, the MFDS, and MAFRA in Korea is critical. Korean regulatory authorities should actively communicate and collaborate to follow global trends in safety assessments and rapidly developing alternative tests.

\section{Acknowledgements}

This study was supported by a grant of the Korean Health Technology R\&D Project, Ministry of Health and Welfare, Republic of Korea (grant no. HN13C0077).

\section{Conflict of Interest}

The authors have no conflicts of interest associated with material presented in this paper.

\section{ORCID}

Soojin Ha http://orcid.org/0000-0002-4410-4405

Troy Seidle http://orcid.org/0000-0002-1341-2181

Kyung-Min Lim http://orcid.org/0000-0002-1517-7680

\section{References}

1. US Government Accountability Office. Toxic Substances Control Act: preliminary observations on legislative changes to make TSCA more effective; 1994 [cited 2016 Dec 27]. Available from: http://www.gao. gov/products/T-RCED-94-263.

2. Kim KY, Shin SE, No KT. Assessment of quantitative structure-activity relationship of toxicity prediction models for Korean chemical substance control legislation. Environ Health Toxicol 2015;30 Suppl: s2015007.

3. Yoon C, Ham S, Park J, Kim S, Lee S, Lee K, et al. Comparison between the chemical management contents of laws pertaining to the Ministry of Environment and the Ministry of the Employment and Labor. J Environ Health Sci 2014;40(5):331-345 (Korean).

4. Park D. Major concerns regarding lung injury and related health conditions caused by the use of humidifier disinfectant. Environ Health Toxicol 2016;31:e2016014.

5. Paek D, Koh Y, Park DU, Cheong HK, Do KH, Lim CM, et al. Nationwide study of humidifier disinfectant lung injury in South Korea, 1994-2011. Incidence and dose-response relationships. Ann Am Thorac Soc 2015;12(12):1813-1821.

6. Hong S. Understanding Asian green chemistry regulations: chemicals substitution. Chim Oggi 2015;33(1):63-64.

7. Ministry of Government Legislation. Act on the Registration and Evaluation, etc. of Chemical Substances [cited 2014 Dec 30]. Available from: http://www.law.go.kr/lsInfoP.do?lsiSeq=140402\#0000 (Korean).

8. United Nations Economic Commission for Europe. Globally harmonized system of classification and labelling of chemicals (GHS): third revised edition; 2009 [cited 2016 Dec 15]. Available from: https:// www.unece.org/trans/danger/publi/ghs/ghs_rev03/03files_e.html.

9. Ball N, Bartels M, Budinsky R, Klapacz J, Hays S, Kirman C, et al. The challenge of using read-across within the EU REACH regulatory framework; how much uncertainty is too much? Dipropylene glycol methyl ether acetate, an exemplary case study. Regul Toxicol Pharmacol 2014;68(2):212-221.

10. Ministry of Agriculture, Food and Rural Affairs. Animal protection and welfare survey report 2015 [cited 2016 Dec 15]. Available from: http://www.mafra.go.kr/list.jsp?\&newsid=155448053\&section_id=b_ sec_1\&pageNo $=1 \&$ year $=2016 \&$ listent $=10 \&$ board_kind $=$ C\&board skin_id=C3\&depth $=1 \&$ division $=$ B\&group_id $=3 \&$ menu $\mathrm{id}=1125 \&$ reference $=\&$ parent_code $=3 \&$ popup_yn $=\&$ tab_yn $=\mathrm{N}(\mathrm{Ko}-$ rean).

11. Pedersen F, de Bruijn J, Munn S, van Leeuwen K. Assessment of additional testing needs under REACH: effects of (Q)SARS, risk based testing and voluntary industry initiatives; 2003 [cited 2016 Dec 15]. Available from: http://home.kpn.nl/reach/downloads/reachtestingneedsfinal.pdf.

12. van der Jagt K, Munn S, Tørsløv J, de Bruijn J. Alternative approaches can reduce the use of test animals under REACH; 2004 [cited 2016 Dec 15]. Available from: http://publications.jrc.ec.europa.eu/repository/bitstream/JRC29111/EUR\%2021405\%20EN.pdf.

13. Hartung T, Rovida C. Chemical regulators have overreached. Nature 2009;460(7259):1080-1081.

14. Leist M, Hartung T. Inflammatory findings on species extrapolations: humans are definitely no 70-kg mice. Arch Toxicol 2013;87(4):563567. 
15. McGonigle P, Ruggeri B. Animal models of human disease: challenges in enabling translation. Biochem Pharmacol 2014;87(1):162-171.

16. Pastoor T, Stevens J. istorical perspective of the cancer bioassay. Scand J Work Environ Health 2005;31 Suppl 1:129-140.

17. Holmes AM, Solari R, Holgate ST. Animal models of asthma: value, limitations and opportunities for alternative approaches. Drug Discov Today 2011;16(15-16):659-670.

18. Vandenberg LN, Colborn T, Hayes TB, Heindel JJ, Jacobs DR Jr, Lee $\mathrm{DH}$, et al. Hormones and endocrine-disrupting chemicals: low-dose effects and nonmonotonic dose responses. Endocr Rev 2012;33(3): 378-455.

19. Olson H, Betton G, Stritar J, Robinson D. The predictivity of the toxicity of pharmaceuticals in humans from animal data--an interim assessment. Toxicol Lett 1998;102-103:535-538.

20. Food and Drug Administration. Innovation or stagnation: challenge and opportunity on the critical path to new medical products; 2004 [cited 2016 Dec 15]. Available from: http://www.fda.gov/downloads/ ScienceResearch/SpecialTopics/CriticalPathInitiative/CriticalPathOpportunitiesReports/UCM113411.pdf.

21. Venter JC, Adams MD, Myers EW, Li PW, Mural RJ, Sutton GG, et al. The sequence of the human genome. Science 2001;291(5507):13041351.

22. Newmark PA, Sánchez Alvarado A. Not your father's planarian: a classic model enters the era of functional genomics. Nat Rev Genet 2002;3(3):210-219.

23. Sundberg SA. High-throughput and ultra-high-throughput screening: solution- and cell-based approaches. Curr Opin Biotechnol 2000; 11(1):47-53

24. Tennant RW. The National Center for Toxicogenomics: using new technologies to inform mechanistic toxicology. Environ Health Perspect 2002;110(1):A8-A10.

25. Krewski D, Acosta D Jr, Andersen M, Anderson H, Bailar JC 3rd, Boekelheide $\mathrm{K}$, et al. Toxicity testing in the 21st century: a vision and a strategy. J Toxicol Environ Health B Crit Rev 2010;13(2-4):51-138.

26. Fentem J, Chamberlain M, Sangster B. The feasibility of replacing animal testing for assessing consumer safety: a suggested future direction. Altern Lab Anim 2004;32(6):617-623.

27. Ashton R, De Wever B, Fuchs HW, Gaca M, Hill E, Krul C, et al State of the art on alternative methods to animal testing from an industrial point of view: ready for regulation? ALTEX 2014;31(3):357-363.

28. Organization for Economic Cooperation and Development. Test No. 492: reconstructed human cornea-like epithelium (RhCE) test method for identifying chemicals not requiring classification and labelling for eye irritation or serious eye damage; 2015 [cited 2016 Dec 26]. http:// www.oecd-ilibrary.org/environment/test-no-492-reconstructed-hu- man-cornea-like-epithelium-rhce-test-method-for-identifying-chemicals-not-requiring-classification-and-labelling-for-eye-irritation-or-serious-eye-damage 9789264242548 -en.

29. Debbasch C, Ebenhahn C, Dami N, Pericoi M, Van den Berghe C, Cottin M, et al. Eye irritation of low-irritant cosmetic formulations: correlation of in vitro results with clinical data and product composition. Food Chem Toxicol 2005;43(1):155-165.

30. Organization for Economic Cooperation and Development. Test No. 405: acute eye irritation/corrosion; 2012 [cited 2016 Dec 15]. Available from: http://www.oecd.org/env/test-no-405-acute-eye-irritationcorrosion-9789264185333-en.htm.

31. Organization for Economic Cooperation and Development. Test No. 492: reconstructed human cornea-like epithelium (RhCE) test method for identifying chemicals not requiring classification and labelling for eye irritation or serious eye damage; 2015 [cited 2016 Dec 15]. Available from: http://www.oecd-ilibrary.org/environment/test-no-492-reconstructed-human-cornea-like-epithelium-rhce-test-method-for-identifying-chemicals-not-requiring-classification-and-labelling-for-eye-irritation-or-serious-eye-damage_9789264242548-en.

32. Organization for Economic Cooperation and Development. Test No. 429: skin sensitisation: local lymph node assay; 2010 [cited 2016 Dec 15]. Available from: http://www.oecd.org/env/test-no-429-skin-sensitisation-9789264071100-en.htm.

33. Jaworska J, Harol A, Kern PS, Gerberick GF. Integrating non-animal test information into an adaptive testing strategy - skin sensitization proof of concept case. ALTEX 2011;28(3):211-225.

34. Tollefsen KE, Scholz S, Cronin MT, Edwards SW, de Knecht J, Crofton $\mathrm{K}$, et al. Applying adverse outcome pathways (AOPs) to support Integrated Approaches to Testing and Assessment (IATA). Regul Toxicol Pharmacol 2014;70(3):629-640.

35. National Institute of Environmental Research. National Institute of Environmental Research test guidelines for K-REACH: 2015-28 [cited 2016 Dec 15]. Available from: http://www.nier.go.kr/NIER/cop/ bbs/selectNoLoginBoardList.do?bbsId=BBSMSTR_000000000031\& menuNo=15001 (Korean).

36. European Chemicals Agency. REACH legislation [cited 2016 Dec 26]. Available from: https://echa.europa.eu/regulations/reach/legislation.

37. Shrout PE, Fleiss JL. Intraclass correlations: uses in assessing rater reliability. Psychol Bull 1979;86(2):420-428.

38. Home Office; Department for Business, Innovation \& Skills; Department of Health. Working to reduce the use of animals in scientific research; 2014 [cited 2016 Dec 15]. Available from: https://www.gov. uk/government/uploads/system/uploads/attachment_data/file/277942/ bis-14-589-working-to-reduce-the-use-of_animals-in-research.pdf. 